\title{
PROPOSAL USAHA PEMBUATAN PRODUK PERIKANAN \\ EMPEK - EMPEK IKAN BELIDA
}

DISUSUN OLEH:

RAVLI R. ADAM

1121418011

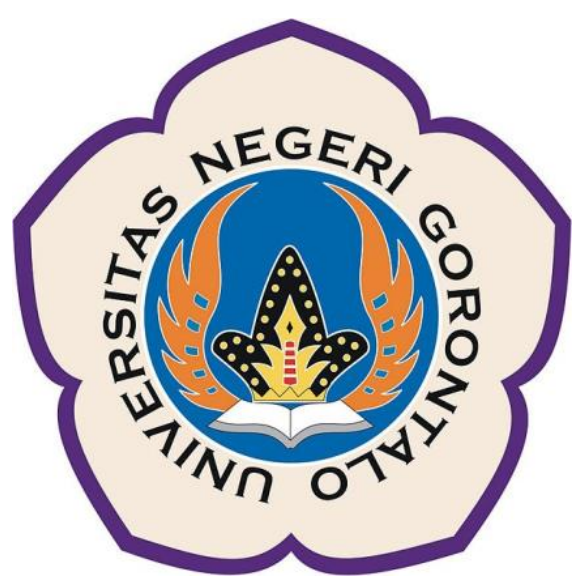

JURUSAN TEKNOLOGI HASIL PERIKANAN

FAKULTAS PERIKANAN DAN ILMU KELAUTAN

UNIVERSITAS NEGERI GORONTALO

2021 


\section{DAFTAR ISI}

KATA PENGANTAR

DAFTAR ISI

BAB I PENDAHULUAN

1.1 Latar Belakang.

1.2 Tujuan.

1.3 Manfaat.

BAB II GAMBARAN UMUM RENCANA USAHA

2.1 Analisis Peluang Pasar.

2.3 Tingkat Persaingan

BAB III METODE PELAKSANAAN

3.1 Rencana Pelaksanaan.

3.2 Proses Produksi.

BAB IV 


\section{BAB I \\ PENDAHULUAN}

\subsection{Latar Belakang}

Pada awalnya pempek berasal dari daerah Palembang dan dibuat dari mencampurkan daging ikan giling lalu dicampur dengan tepung tapioka, sehingga dihasilkan makanan baru dan pada perkembangan selanjutnya disebut dengan PEMPEK.Dahulu ikan yang digunakan adalah ikan belida.Namun, dengan semakin langka dan mahalnya harga ikan belida, ikan tersebut diganti dengan ikan gabus yang harganya lebih murah, tetapi dengan rasa yang tetap gurih.Pada perkembangan selanjutnya, digunakan juga jenis ikan sungai lainnya, misalnya ikan putak, toman, dan bujuk.Dipakai juga jenis ikan laut seperti Tenggiri, Kakap Merah, parang-parang, ekor kuning, dan ikan sebelah.Jenis ikan yang biasa dipakai untuk membuat empek-empek yaitu Ikan Belida, Ikan Gabus, Ikan Tenggiri, Ikan Parang-parang. Namun jika tidak menemukan ikan tersebut, biasanya ada jenis ikan pengganti yang sering dipakai jika ikan-ikan diatas sukar di dapat yaitu Ikan Putak, Ikan Toman, Ikan sarden/layang/tamban, kakap merah, Sepat Siam, dan Bilis besar.

Pada prinsipnya, semua ikan tawar dan laut bisa dipakai untuk bahan membuat pempek, hanya ikan laut lebih amis baunya dan terkadang banyak yang alergi. Pempek adalah salah satu makanan khas yang digemari oleh kebanyakan masyarakat di Indonesia.

1) Bagaimana meningkatkan dan menumbuhkan daya kreatifitas mahasiswa dalam berwirausaha?

2) Bagaimana menciptakan kreasi makanan yang bermanfaat bagi masyarakat?

3) Bagaimana memanfaatkan jajanan pasar yaitu pempek menjadi makanan yang menyehatkan? 


\subsection{Tujuan}

Tujuan secara khusus yang ingin dicapai dari penyelenggaraan kegiatan usaha adalah memperluas kesempatan kerja kepada masyarakat. Selain itu tujuan secara umum sebagai berikut:

1) Meningkatkan kreativitas kewirausahaan kami dan masyarakat,

2) Meningkatkan hasil produktivitas pengolahan pempek,

3) Menambah wawasan kami dan masyarkat tentang pengolahan pempek,

\subsection{Manfaat}

Secara umum manfaat dari program ini untuk memperluas kesempatan kerja kepada masyarakat dan untuk mengaplikasikan hasil kegiatan ini secara professional dalam rangka memenuhi kebutuhan hidup secara mandiri

1) Meningkatkan minat mahasiswa dalam berwirausaha melalui pengembangan usaha "Pempek Kuah Bakso"

2) Untuk meningkatkan nilai ekonomi pada makanan berbahan dasar Pempek

3) Untuk menghasilkan suatu produk jajanan alternatif berbahan baku pempek yang sehat dan aman untuk dikonsumsi. 


\section{BAB II}

\section{GAMBARAN UMUM RENCANA USAHA}

\subsection{Analisis Peluang Pasar}

Melihat perkembangan industri yang sedang menjamur dikalangan anak muda, hal ini memicu kami untuk turut andil dalam kegiatan yang bermanfaat karena melihat peluang usaha yang begitu besar dimanfaatkan untuk turut memproduksi suatu olahan pempek yang bermanfaat bagi konsumen.

Apalagi olahan pempek menjadi pempek kuah bakso belum ada dikalangan masyarakat Indonesia, meskipun pempek bukan makanan asing, namun pempek kuah bakso merupakan terobosan baru dalam menciptakan makanan khususnya jajanan pasar yang sehat dan higienis.Produk ini merupakan suatu kombinasi antara kualiatas yang baik serta kemasan yang menarik dengan harga terjangkau, sehingga target atau sasaran dari pemasaran kami melingkupi semua lapisan masyarakat.

\subsection{Tingkat Persaingan}

Melihat situasi di tempat yang akan dimasuki produk, sepertinya produk pempek kuah bakso ini akan laku di pasaran. Hal ini dikarenakan harganya yang terjangkau dan sangat pas untuk ukuran dompet mahasiswa. Selain itu pesaing yang akan menyaingi produk ini tampaknya belum ada khususnya di kampus Universitas Islam Malang

Selain itu kami akan melakukan penjualan secara pesanan dalam jumlah banyak dengan menggunakan jejaring sosial seperti blog, facebook dan BBM sehingga penjualan ini tidak akan vakum dan akan mampu bersaing secara global dan tidak akan monoton sehingga akan mampu berkelanjutan. 
Dalam persaingan pasar kami akan menigkatkan inovasi dalam jangka waktu tertentu sesuai perkembangan zaman dan permintaan konsumen seperti akan memperkaya rasa, warna dan mempercantik kemasan. 


\section{BAB III \\ METODE PELAKSANAAN}

\subsection{Rencana Pelaksanaan}

\subsubsection{Product (produk)}

Produk yang direncanakan untuk diproduksi adalah pempek kuah bakso yang memiliki kualitas yang tinggi dan kandungan gizi yang bermanfaat untuk tubuh manusia.

Dalam menjalankan sebuah kegiatan apalagi wirausaha, tentunya diiperlukan berbagai persiapan dan perencanaan yang matang sehingga orientasi dari usaha tersebut dapat dicapai. Adapun tahapan-ahapan tersebut sebagai berikut:

1) Tahapan Perencanaan

Merencanakan sebuah usaha merupakan mutlak diperlukan guna mendukung kegiatan wirausaha. Perencanaan dalam usaha pembuatan pempek kuah bakso yaitu memulai dengan rencana konsepan komposisi yang banyak mengandung vitamin dan gizi yang baik bagi kesehatan, sampai pada tahap distribusi dan marketing untuk menghindari atau meminimalisir kendala yang akan dihadapi.

2) Tahap Pembelian Bahan Baku

Setelah melewati tahapan perencanaan, maka tahapan selanjutnya adalah pembelian bahan baku baku yang sudah diperlukan untuk pembuatan pempek kuah bakso.

3) Tahap Produksi

Inilah bagian yang paling penting dalam usaha ini, bagaimana perencanaan yang ada dalam konsepan yang diaplikasikan untuk menjadi suatu produk yang nyata. 


\subsubsection{Place (lokasi/distribusi)}

Untuk tempat pemasaranya akan kami lakukan di sekitar kampus Universitas Islam Malang Adapun sasaran pasar poduk adalah ini adalah mahasiswa di Universitas Islam Malang dan disekitar kampus juga terdapat sekolah SD dan TK dimana produk kami akan banyak digemari oleh kalangan anak-anak. Selain itu kami akan melakukan transaksi secara online di jejaring sosial dan internet sebagai bahan penunjang perkembangan usaha.

\subsubsection{Price (harga)}

Penentuan harga jual dilakukan dengan cara menghitung biaya produksi ditambah biaya lain-lain .

Asumsi daftar harga produk dan perkiraan penjualan per hari.

\begin{tabular}{|l|l|l|l|l|}
\hline No & Jenis Pempek & Harga Satuan & $\begin{array}{l}\text { Jumlah } \\
\text { penjualan/hari }\end{array}$ & Total \\
\hline 1. & Pempek Telur & Rp. $3.000,00$ & 20 Buah & Rp.60.000,00 \\
\hline 2. & Pempek Panggang & Rp.3.000,00 & 20 Buah & Rp.60.000,00 \\
\hline 3. & $\begin{array}{l}\text { Pempek alphabet (huruf dan } \\
\text { angka) }\end{array}$ & Rp.3.000,00 & 20 Buah & Rp.60.000,00 \\
\hline 4. & Pempek sosis & Rp.3.000,00 & 20 Buah & Rp.60.000,00 \\
\hline 5. & Pempek Kapal Selam & Rp.7.000,00 & 15 Buah & Rp.105.000,00 \\
\hline & & & Total & Rp.345.000,00 \\
\hline
\end{tabular}

2. Penerimaan :

Total Penerimaan perbulan : Total penerimaan perhari x 30 hari

$$
\text { Rp. } 345.000,00 \times 30=\text { Rp. 10.350.000,00 / bulan }
$$


Jadi Keuntungan yang Diperoleh perbulan adalah $\quad$ :

Keuntungan $=$ Total Penerimaan perbulan - Total Pengeluaran perbulan

$$
\begin{aligned}
& =\text { Rp. } 10.350 .000,00-\text { Rp. } 6.000 .000,00 \\
& =\quad \text { Rp.4.350.000,00 / bulan }
\end{aligned}
$$

\subsubsection{Promotion (promosi)}

Promosi akan dilakukan untuk mengenalkan produk ini kepada konsumen. Promosi akan dilakukan dengan menempel pamflet-pamflet di pinggir jalan dan tempat-tempat strategis lainnya. Selain itu juga akan memanfaatkan buletin yang terbit di kampus dan media internet sebagai sarana e-business.

Penggunaan media handphone, facebook, dan twitter merupakan media yang sangat efektif untuk menjalankan wirausaha ini. Selain itu, dengan adanya media online tersebut akan mempermudah usaha ini dalam mempromosikan atau memperkenalkan produk PEMPEK KUAH BAKSO kepada konsumen. Karena pada dasarnya internet dapat diakses oleh siapa saja, kapan saja, dsan dimana saja.Hal inilah yang mendorong untuk menggunakan internet sebagai media sarana inilah yang mendorong untuk menggunakan internet sebagai sarana promosi (advertising) yang efektif dan efisien.Namun, penggunaan internet bukanlah satusatunya yang digunakan untuk promosi.Karena sistem mouth to mouth juga dianggap efektif untuk promosi produk karena dapat secara langsung bertemu dengan konsumen yang menjadi objek dari usaha ini. 


\subsection{Proses Produksi}

\subsubsection{Bahan pempek tenggiri}

Bahan yang digunakan untuk membuat pempek tenggiri adalah :

1) $1 \mathrm{Kg}$ tepung sagu yang berkualitas baik

2) $1 \mathrm{~kg}$ daging ikan tenggiri yang sudah digiling halus

3) $250 \mathrm{ml}$ air es

4) Air bersih secukupnya untuk direbus

5) 1 sendok teh garam halus

6) Bawang putih yang sudah dihaluskan

7) Minyak untuk menggoreng

Bahan-Bahan Untuk Membuat Kuah Bakso

Adapun beberapa bahan yang digunakan untuk membuat kuah bakso sebagai berikut.

1) Air mineral sebanyak 4 liter

2) Tulang sapi sebanyak 400 gram

3) Lada bubuk sebanyak $1 \mathrm{sdm}$

4) Daun bawang sebanyak yang dicincang kecil-kecil

5) Bawang putih sebanyak 12 siung yang dihaluskan

6) Garam secukupnya

Cara Membuat Kuah Bakso

Bahan-bahan yang digunakan untuk membuat kuah bakso.

1) Cara membuat kuah bakso enak sedap yang pertama adalah memasukkan air mineral ke dalam panci. Dalam panci tersebut, tambahkan tulang sapi. Untuk mempermudah pemasakan, anda bisa memotong-motong tulang sapi sesuai dengan selera anda. 
2) Dengan api sedang, tunggu sampai air berisi tulang sapi mendidih, baru kemudian kecilkan apinya.

3) Tambahkan bawang putih dalam panci, selama kurang lebih 15 menit hingga 30 menit.

4) Baru setelah itu, tambahkan bumbu-bumbu lainnya seperti garam, lada bubuk dan gula pasir ke dalam panci.

5) Aduk kuah bakso tersebut dan cicipi rasanya. Jika dirasa kurang asin, anda bisa menambahkan garam sesuai dengan kebutuhan.

6) Tunggu sampai kuah mendidih kembali. Jika kuah tersebut terasa kurang gurih, anda bisa menunggu lebih lama lagi, Untuk membiarkan tulang yang dimasukkan mengeluarkan aroma sedap pada kuah yang anda masak.

\section{Cara Membuat pempek :}

Cara membuat pempek sebagai berikut.

1) Masukkan ikan yang sudah dihaluskan dalam satu wadah tambahkan garam,penyedap rasa dan air es aduk sampai rata

2) Masukkan tepung sedikit demi sedikit sambil diuleni dengan tangan sampai adonan pas dan kalis

3) Ambil adonan pempek secukupnya lalu dibentuk sesuai selera

\subsubsection{CARA MEMASAK PEMPEK}

cara memasak pempek sebagai berikut.

1) Didihkan sepanci air dengan 2 sdm minyak goreng (untuk mencegah pempek lengket).

2) Masukan adonan pempek yg sudah dibentuk.

3) Biarkan sampai mengapung, angkat dan tiriskan.

4) Setelah dingin, goreng dalam minyak panas sampai kecoklatan

5) Kemudian iris pempek sesuai selera tambahkan mie putih dan mentimun yang sudah diiris kemudian tambahkan kuah bakso yang sudah disiapkan 
6) Bisa juga menikmatinya dengan saus,kecap manis dan cabe sesuai selera Tips :

1) Makin segar ikan, makin baik hasil pempek yang Anda buat.

Usahakan menyimpannya dalam lemari pendingin ataufreezer sampai beku, kalau mau dibikin baru keluarin dari kulkas biarkan sampai setengah beku lalu uleni.jadi padasaat diuleni masih ada sisa sisa esnya.

2) Bahan ikan, jika ikan tenggiri rasa pempek lebih getas sedikit kenyal tapi lembut. Bisa dipakaiikan kakap, tuna, bahkan ikan sepat, sarden pun boleh.Jika ikan gabus, pempek akan lembut dan gurih.

3) Boleh diganti dengan ikan lain, seperti sepat siam besar, parang-parang, ikan sarden (warnpempek akan sedikit hitam), prinsipnya... semua jenis ikan kecil bisa dijadikan bahan dasarpempek.

4) Banyak variasi resep pempek yang ada. Yang patut diingat, semakin banyak cairan (air), makinbanyak kanji yang harus ditambahkan. Biasanya, hasilnya jadi makin kenyal.

Catatan untuk diperhatikan:

Ikan sebagai bahan utama untuk membuat pempek haruslah berasal dari ikan yang memiliki nilai protein dan lemak yang cukup untuk menunjang kesehatan. Selain itu ikan yang akan diolah juga merupakan ikan segar sehingga kualitas kandungan gizinya masih terjaga dengan baik. Untuk membuat pempek ikan haruslah digiling atau dihaluskan terlebih dahulu dengan alat penggilingan khusus sehingga daging ikan akan terpisah dengan kulit dan bagian-bagian tulang ikan atau bagian-bagian lainnya yang tidak dimanfaatkan untuk membuat pempek.

\subsubsection{Proses Finishing:}

1) biarkan pempek dingin terlebih dahulu

2) masukkan pempek kedalam wadah yang sudah disiapkan dan Sudah Disablon Label

3) siapkan kuah bakso yang sudah dimasukkan kedalam plastik

4) pempek kuah bakso siap dijual dan dipasarkan 


\section{DAFTAR PUSTAKA}

Sun, X., Liu, J., Dai, X., Wang, X., Yapanto, L. M., \& Olegovna, A. (2021). On the application of surfactant and water alternating gas ( $\mathrm{SAG} / \mathrm{WAG}$ ) injection to improve oil recovery in tight reservoirs. Energy Reports, 7, 2452-2459. https://doi.org/10.1016/j.egyr.2021.04.034

Yapanto LM, Musa Farid TH. 2018. Distribution of Seafood Production in Bajo Sector of Gorontalo Province Indonesia. International Journal of Innovative Science and Research Technology. 3(8): 521-523

Lis Melissa Yapanto, M. L. M. (2018). Assessing public awareness level on the preservation of coral reefs (The case study in Biak Numfor, Papua, Indonesia). In Copyright@EM International (Vol. 24, Issue 4).

Yapanto, L.M., \& Modjo, M.L. (2018). Assessing public awareness level on the preservation of coral reefs (The case study in Biak Numfor, Papua, Indonesia). In Copyright@EM International (Vol. 24, Issue 4).

Zakaria, A. (2005). Penanggulangan Kemiskinan Pada Petani Berlahan Sempit di Agroekosistem Lahan Kering Dataran Tinggi Berbasis Sayuran. Soca (Socio-Economic of Agriculturre And.

Setiawan, R., Pio, L., Cavaliere, L., Sankaran, D., Rani, K., Yapanto, L. M., Laskar, N. H., Raisal, I., Christabel, G. J. A., Setiawan, R., Petra, U. K., Airlangga, U., Pio, L., Cavaliere, L., \& Foggia, U. (n.d.). Access to Financial Services and Women Empowerment, through Microfinance eligibility. 1, 841-859.

Yapanto, L. M., \& Nursinar, S. (n.d.). Traditional Handline Fishing in Pohuwato Regency, Indonesia. 6, 24-30.

Yapanto LM, Musa Farid TH. 2018. Distribution of Seafood Production in BajoSector of Gorontalo Province Indonesia. International Journal of Innovative Science and Research Technology. 3(8): 521-523 